\title{
'Crippled with nerves': popular music and polio, with particular reference to Ian Dury
}

\author{
GEORGE McKAY \\ CCM Research Centre, Adelphi House, University of Salford, Manchester M3 6EN, UK \\ E-mail: g.a.mckay@salford.ac.uk
}

\begin{abstract}
This article looks at a remarkable cluster of popular musicians who contracted and survived poliomyelitis ('infantile paralysis') epidemics through the twentieth century, and ways in which they managed and, to varying extents, explored their polio-related impairments and experiences in their music. Drawing on medical history and disability studies, it focuses largely on the pop and rock generation of polio survivors - the children and young people from the 1940s and 1950s who were among the last to contract the disease prior to the successful introduction of mass vaccination programmes (in the West). These include Neil Young, Steve Harley, Joni Mitchell, and Israel Vibration. The article then looks in detail at the work of Ian Dury, who was for a while the highest profile visibly physically disabled pop artist in Britain, and who produced a compelling body of works exploring the experiences of disability.
\end{abstract}

\section{Introduction}

This article focuses largely on the rock and roll generation of polio survivors: children and young people from the late 1940s to the early 1950s who contracted poliomyelitis ('infantile paralysis') during summer epidemics in the last few years before reliable vaccinations were widely available (in the West). In using polio as the focusing device I am aware that I may seem to be privileging the medical condition and its consequent disabilities over the people, the artists concerned, and their cultural products. But I am interested in the historical specificity of the disease in the post-war West. The introduction of the vaccines that successfully eradicated polio within a few years made that generation dramatically the last (in the West), while the chronological coincidence of the rise of pop culture would lead in a decade or two to a remarkable generation of pop and rock musicians who had been shadowed by 'the crippler', as polio was known colloquially in the USA. ${ }^{1}$ I discuss these, and go on to look at the work of Ian Dury, who was for a while the highest profile visibly physically disabled pop artist in Britain. This made Dury 'one of society's ultimate "not me" figures' in the cultural context of the wannabe pop world, of course, but he is of special interest due to his songs around the topic of disability, his inventive and provocative 'narratives of corporeal/cultural difference', in Rosemarie Garland Thomson's terms (Thomson 1997, pp. 16, 41). 
Through the twentieth century, increasing public awareness of polio outbreaks (epidemics in New York in 1916, Los Angeles in 1934, Berlin in 1947, Copenhagen in 1952) caused periodic panic among local populations. As Marc Shell writes in Polio and its Aftermath, 'For seventy years, polio traumatized the world ... An American president suffered from its paralyzing effects. So did sixty million other people worldwide. Even when polio did not kill its victims outright, it often crippled them for life. The survivors were the visible reminder of polio's ever-increasing power to slay, maim, and deform ... No one knew what caused the disease, and there was no cure' (Shell 2005, p. 1). But, according to Tony Gould in A Summer Plague, '[e]verything to do with polio in Britain, not least the disease itself, was on a minor scale' (Gould 1995, p. 161). This changed with the epidemic of 1947, in which 7,776 people contracted the disease. Over the following decade some 58,000 were affected, around 4,000 of whom died, and of the survivors 35,000 were left with a degree of paralysis (Balls 2000, pp. 32-3). ${ }^{2}$ One medical student working in a London hospital during one outbreak in the 1950s, when hospital staff were themselves coming down with the disease, described this plague-like situation as 'absolutely bloody terrifying' (quoted in Gould 1995, p. 162). At this time, the 1950s being the high point of the 'polio zeitgeist' (Gould 1995, p. 219), the Salk vaccine was available in Britain for young people (by injection), though not yet widely used. (It would be superseded within a few years by the Sabin vaccine, dispensed nationwide to schoolchildren on sugar cubes.) $)^{3}$ Polio is a highly contagious viral disease that can attack the body's nervous system. Transmitted by faecally contaminated food and water, in temperate climates it is a seasonal disease, therefore summer swimming in pools and lakes was a childhood activity feared and discouraged by many parents. Also, polio is primarily a disease of children. Its characteristic operation is that by attacking nerve cells the virus permanently paralyses the activated muscles. So, while Ian Dury in the early 1970s would write and sing a halting love song, 'Crippled with nerves', a highlight of his band's live set (released as a single in 1975), the title phrase itself was both resonant and neurologically informed: Dury was indeed crippled with (by) his nerves. Or, as Canadian singer-songwriter and polio survivor Joni Mitchell has put it:

Polio is the disease that eats muscles. If it eats the muscle of your heart, it kills you; if it eats the muscles that control the flexing of your lungs, you end up in an iron lung; if it eats the muscle of your leg, it withers, or of your arm, it withers. In my case it ate muscles in my back - the same thing happened with Neil Young. I had to learn to stand [again], and then to walk. (quoted in Matteo [n.d.])

A notable number of children and young people who would go on to make their mark in various music fields were struck by 'the crippler'. The Table doubtless contains an incomplete list, but it is one that illustrates the numbers involved, as well as the geographical and musical distribution. As noted, this medical-musical cluster can be partly explained by the concurrence of polio epidemics with the childhood years of an early pop and rock generation, dramatised - or made poignant - by virtue of the fact that many of these young people were among the last ever to contract the disease (in the West). ${ }^{5}$ So, broadly speaking, while those who contracted polio in the 1940s and 1950s on this list were in Tony Gould's phrase 'born too soon' (Gould 1995, p. 188) in the sense that they were too young to benefit from the imminent introduction of the vaccines, they were also born at just the right time to feel the beat of the rock and pop worlds of youth music, the counterculture and beyond. (There is a wider coincidence of polio occurrence and mass communications technologies in the twentieth century, as Marc Shell has identified: 'During 


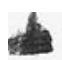

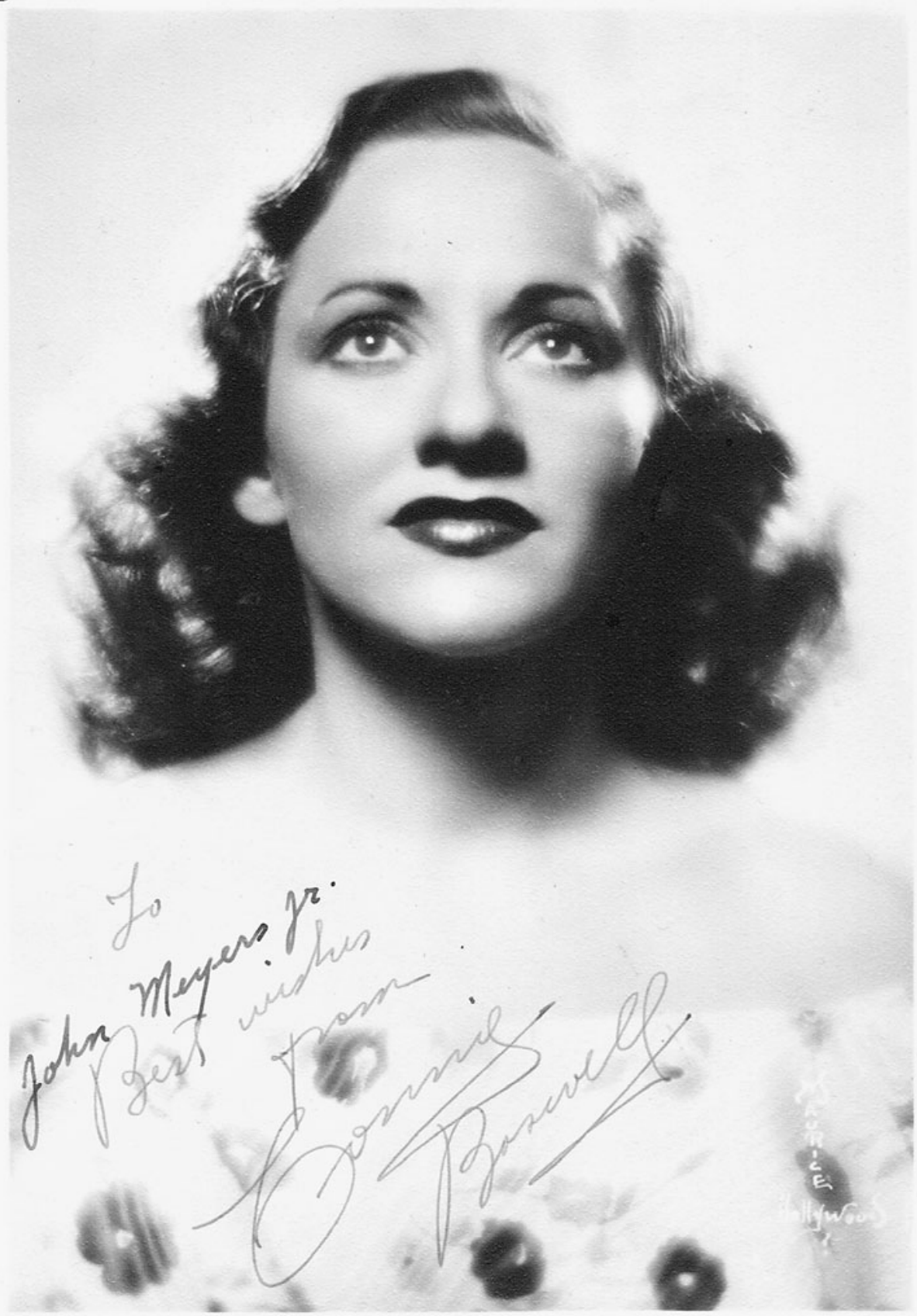

Figure 1. Connie Boswell publicity card, 1938/1944. Author's collection.

the seventy years in which polio epidemics were widespread, the various electronic media - cinema, radio, television - were also coming into their own'; Shell 2005, p. 1.)

\section{CAMBridge JDUANALS}


Table. Popular musicians who contracted polio.

\begin{tabular}{lll}
\hline \hline Name & Music, location & Polio contracted \\
\hline Connie Boswell $^{4}$ & Singer, actress (USA; see Figure 1) & c. 1910 \\
Dinah Shore & Singer, actress (USA) & 1918 \\
Brownie McGhee & Blues singer and guitarist (USA) & c. 1919 \\
Horace Parlan & Jazz pianist (USA) & 1931 \\
Doc Pomus & Rock and roll songwriter (USA) & 1931 \\
Carl Perkins & Bebop pianist (USA) & c. $1930 \mathrm{~s}$ \\
CeDell Davis & Blues slide guitarist (USA) & c. 1936 \\
Michael Flanders & Music hall/radio singer (UK) & 1943 \\
Ray Peterson & Pop singer (USA) & c. $1940 \mathrm{~s}$ \\
Judy Collins & Folk singer (USA) & c. 1950 \\
Walter Jackson & Soul singer (USA; see Figure 2) & $194 / 5 ?$ \\
David Sanborn & Jazz saxophonist (USA) & 1948 \\
Ian Dury & Rock singer (UK) & 1949 \\
Donovan & Folk singer (UK) & 1949 \\
Dave Liebman & Jazz saxophonist (USA) & $194 / 5 ?$ \\
Neil Young & Rock guitarist and singer (Canada) & 1951 \\
Joni Mitchell & Singer-songwriter (Canada) & 1951 \\
Charlie Haden & Jazz bassist (USA) & c. 1952 \\
Gene Simmons & Rock musician (Israeli-born) & c. 1952 \\
Steve Harley & Rock and pop singer (UK) & 1953 \\
Israel Vibration & Reggae vocal trio/duo (Jamaica) & c. $1950 \mathrm{~s}$ \\
\hline \hline
\end{tabular}

I look at this claim, and at ways in which they would find in the youthquake's new sonicities and performative practices opportunities to make sense of their own disabled bodies, to accommodate their childhood 'changes' (Neil Young), to revisit from adulthood their 'dreams of [being] paralysed' (Steve Harley), to sing their medicalised autobiographies: 'If they're caring for me why do they boot me and punch me?' (Ian Dury). The validity of such a connection is interrogated further below.

In March 1962 one of the earliest popular music interventions around polio was made, with the broadcast on BBC Radio's Home Service of Ewan MacColl, Peggy Seeger and Charles Parker's 'radio ballads'. ${ }^{6}$ Entitled The Body Blow, this was the fifth in their innovative series of eight documentaries that combined the sound effects of actualité, the original voices of interviewees recorded in situ, and specially composed folk music by MacColl and Seeger. Subjects of the radio ballads included the working class (train drivers, road builders, fishermen, miners), but also some identity groups at the margins of society (the new teenagers, travellers, and, in The Body Blow, a group of adult polio survivors). Producer Parker explained that he was presenting the intensely personal experience of a group of polio sufferers, with the intention of purging the healthy person's somewhat atavistic fears of the grievously deformed or disabled' (quoted in Cox 2008, p. 122). If the outward aim of the programme was focused on changing the perceptions of the audience towards people with disabilities, the core purpose of the radio ballads in general was to present the authentic voice of the subject. (All five musicians donated their recording royalties for The Body Blow to 


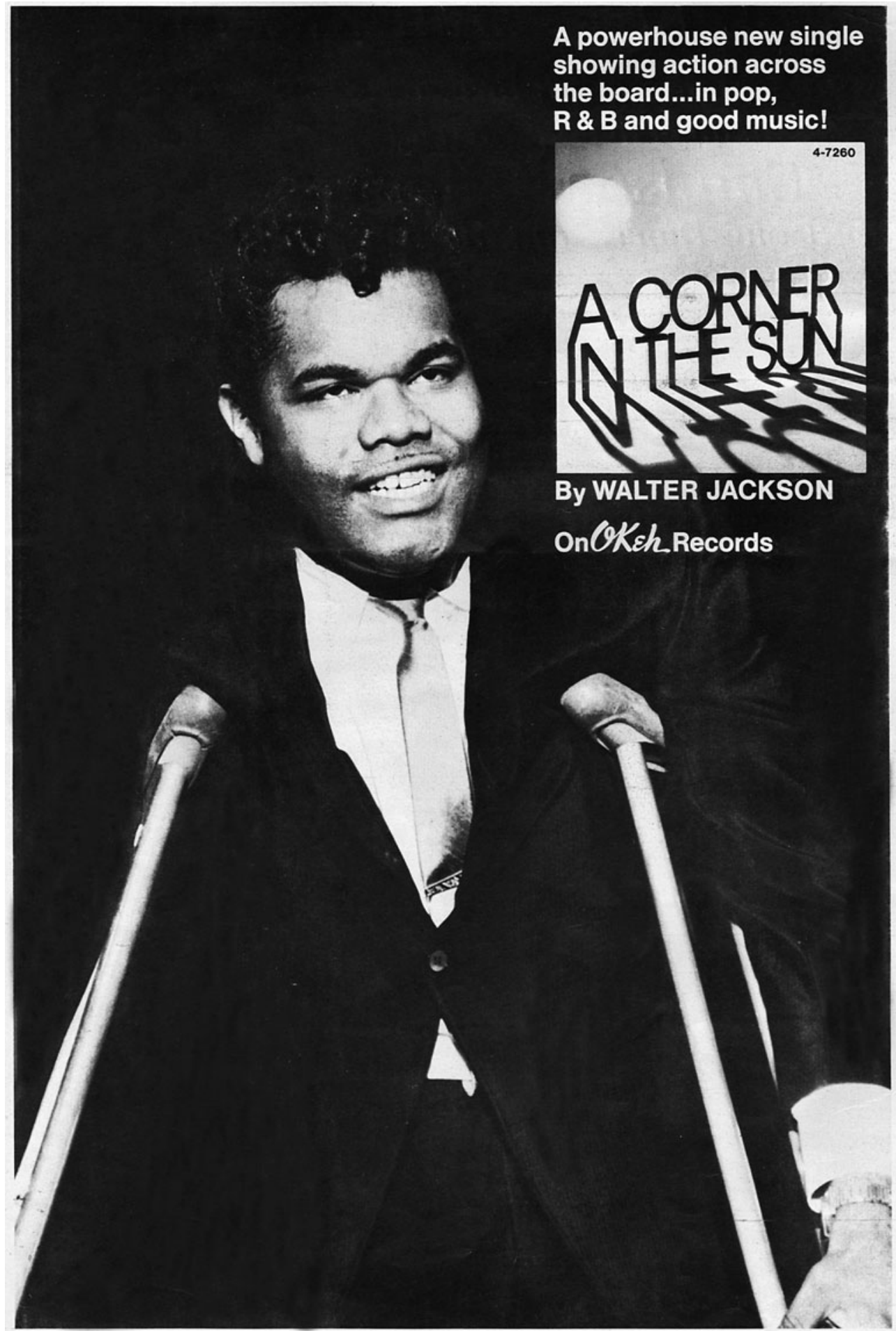

Figure 2. Walter Jackson single advertisement, 1966. (c) Ace Records Ltd, London. Used with permission. 
the Polio Research Fund: Cox 2008, p. 123.) The Body Blow had an intriguing further result. One of the interviewees, Dutchy Holland, was literally part of the programme's restorative project; his capacity to speak depended entirely on the phase of his mechanical ventilator ("he could only speak on the "inspiration" phase of the iron lung's breath': Cox 2008, p. 122). But through the recording and editing of Holland's voice, the programme presented an enabled communication. As the narrator explains approvingly, to Holland's 'machine-chopped speech, the tape recorder, with the editing it makes possible, can restore wholeness' (MacColl et al. 1999).

Although criticised at the time and more recently (see Cox 2008, pp. 126-7, 193-5; Harker 2007, pp.170-1), the actual music in this radio ballad has some moments of wonderful effect, notably in the section 'Can't breathe', which juxtaposes the sound and rhythm of the 'iron lung' with a pared down instrumentation featuring English concertina (an instrument, of course, in which the sounds are produced by mechanical wind manipulation), and MacColl and Seeger's contrasting voices singing lyrics in unison about 'your friendly machine'. The machine's rhythm sets the tempo for the song, while also faintly and pathetically evoking the sound of waves breaking on a beach; the concertina is played so tentatively that its introductory solo notes sound vulnerable, shaky, about to give way. The lyrics admittedly do veer uncertainly between precise well-expressed detail and sentimentality or melodrama, even in the same verse.

Steel and plastic deputy for lungs

Does your breathing for you night and day.

This small machine, your shield, your sword and butler,

Holds death at bay ... (MacColl et al. 1999)

Discussing The Body Blow with Peter Cox in 2007, Peggy Seeger's view of her own contribution was that 'the problem is the singing is too sweet - [it evokes] self pity; it should have been factual singing - this is soppy singing ... [but] I love the tunes' (personal correspondence with Cox, 2008).

There are important considerations concerning the weakened physical body's capacity to make music for the instrumentalists among these polio survivors especially for those from blues, jazz and jazz-tinged musics who valorised instrumental technique as a route to musical individuality. ${ }^{7}$ For instance, Joni Mitchell has explained her unusual guitar chord technique, and hence characteristic acoustic sound, as the result of her attenuated muscularity: 'My left hand is somewhat clumsy because of polio. I had to simplify the shapes of the left hand, but I craved chordal movement that I couldn't get out of standard tuning without an extremely articulate left hand' (quoted in Houston 2000). Mitchell's was a strategy of adaptation, and the resultant music was not heard as an expression of limitation, rather it was prized by her fans as an individual voice. More strikingly perhaps, polio forced the blues guitarist CeDell Davis to 'rethink' his approach to his instrument, and Davis has remained a controversial figure in the blues tradition in part because of his unorthodox musicality. According to blues writer Robert Palmer, who also produced Davis's 1990s recordings,

[Davis explained:] 'I was right-handed, but I couldn't use my right hand, so I had to turn the guitar around; I play left-handed now. But I still needed something to slide with, and my mother had these knives, a set of silverware, and I kinda swiped one of 'em.' This was the beginning of a guitar style that is utterly unique, in or out of blues. The knife-handle on the strings produces uneven pressure, which results in a welter of metal-stress harmonic transients and a singular tonal plasticity. Some people who hear CeDell's playing for the first 


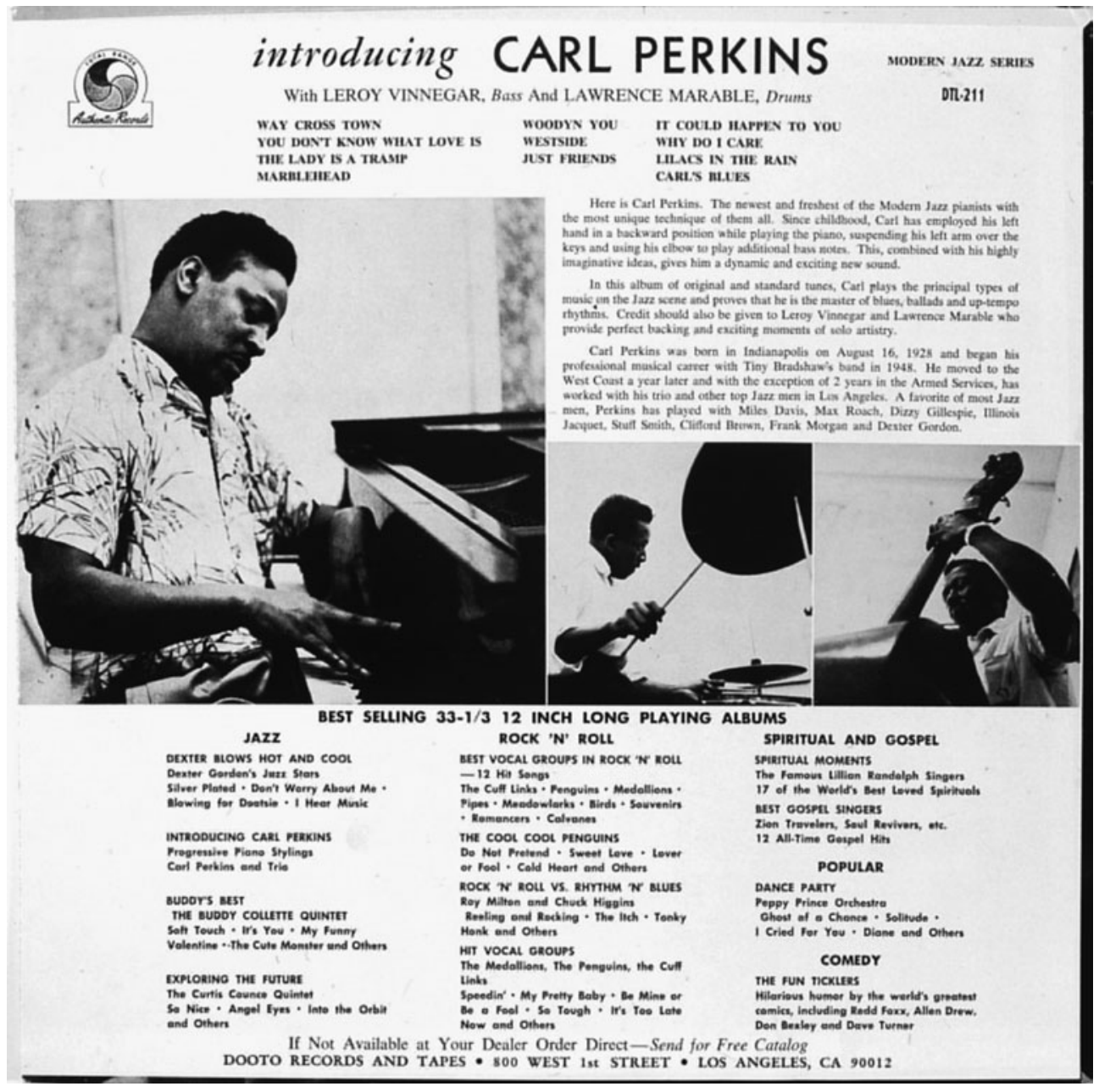

Figure 3. Back cover of 1956 LP, Introducing ... Carl Perkins. (C) Ace Records Ltd, London. Used with permission.

time think it's out of tune, but it would be more accurate to say he plays in an alternative tuning. (Palmer 2004)

Whether 'utterly unique', 'out of tune', or employing an 'alternative tuning', we begin to glimpse within music an adaptive technique which may be both common across polio survivors more widely and the very route away from the commonplace towards the individual.

The West Coast modern jazz pianist Carl Perkins, whose left arm had residual paralysis from childhood polio, played with this arm parallel to the keyboard, and was known as 'the crab' for his sideways-on technique. As Figure 3 shows, the back cover photograph on his only album as leader, Introducing ... Carl Perkins, clearly displays Perkins's physically adapted playing position (Perkins 1956). The sleeve note explains that this approach to the instrument has given him the most unique technique of them all ... [By] suspending his left arm over the keys and using his elbow to play additional bass notes [he has] a dynamic and exciting new sound' 
(Perkins 1956). Arguably, with the compensatory introduction of the elbow as part of the playing body, Perkins's physical incapacity has effectively extended instrumental range. Like another modern jazz pianist, Horace Parlan, Perkins challenges the totality of the assumption that, ' $\mathrm{t}$ ] $\mathrm{o}$ claim the title pianist, one must have two functioning hands' (Lerner 2006, p. 75). Parlan recovered from childhood polio but with his right hand and the right side of his body partially paralysed. This would normally have a greater impact on piano technique than a restricted left hand, such as Perkins's, particularly in jazz where a bassist was usually also present: many bassists expect a lighter touch from the left hand of a pianist when they are playing together, to avoid the muddiness of two sets of bass notes. It was recommended by his childhood doctor that Parlan take up the piano as a form of physiotherapy. Parlan learned to compensate in his piano playing by using his left hand (which usually plays bass notes and chordal accompaniment) also for soloing. This helped him find the kind of alternate individual voice so prized in jazz instrumentalism, as explained admiringly by the English jazz critic Leonard Feather in his sleeve notes for Parlan's first Blue Note album:

The fourth and fifth fingers of the right hand are not used at all. The second and middle fingers, and sometimes the thumb, are used to complete voicings of chords that are basically supplied by the left hand. Occasionally, too, the left hand is used exclusively in single-note lines. Incredible as it may seem, along with all of this, the left hand does a normal job of comping in its regular register. (quoted in Wimmer [n.d.])

Alto saxophonist David Sanborn contracted polio at the age of three in 1948, it dangerously affecting his breathing. He was confined to respiratory treatment (the 'iron lung') for a period and subsequently took up a wind instrument for the purpose of physical therapy (see Sanborn [n.d.]). Both Parlan and Sanborn were encouraged to take up their instruments in childhood as an element of their physiotherapy and recovery; for each, it is arguable that a successful musical career came about because rather than in spite of the childhood disease, musicality originating as a therapeutic response to the residual symptoms of the medical condition.

A cultural cluster like this polio-pop one is also explicable by foregrounding the solitariness and introspection of much treatment of the disease - separated from peers and family, polio children would draw on the artistic compensation of the isolate. Mitchell has spoken of her 'childhood illnesses that developed a solitude and a deepening and fostered "artisticness" ... I think that the creative process was an urgency then, that it was a survival instinct' (quoted in Matteo [n.d.]). The English pop singer Steve Harley spent three-and-a-half childhood years in hospital: 'I wasn't hit badly [by polio], but it changed my life ... For a long time my life was in a bedside cabinet and it was a notebook and pen, all words, words, words ... I am solitary as a result' (quoted in Cooper 2005, p. 48). His long-term impairment consists of atrophied right leg muscles, related limping gait, and permanent uncertainty of balance. At his commercial peak in the mid-1970s, after glam and before punk rock, Harley presented an image of pomp and disturbance with albums like The Psychomodo and The Human Menagerie, playing the poppy madman and decadent, singing songs of suicide and schizophrenia. Although he told me that he never explored any personal sense of disability during the songs of the peak Cockney Rebel years (personal interview, 2005), it is possible to trace some such recurring interest. The 1974 album The Psychomodo presents a fictive figure of combined cognitive and physical impairment. Judging by the front cover which 
shows a bare-shouldered, wide-eyed Harley with a tear rolling down his cheek, fans were invited to identify Harley himself with the disabled Psychomodo character. In the chorus of the album's title song he sings in damaged grammar: 'Oh! We was so hung up and wasted / Oh! We was so physically devastated' (Cockney Rebel 1974).

In the 1980s he came out of semi-retirement to accept the lead role in a new Andrew Lloyd Webber musical, The Phantom of the Opera, in which he would play and sing a disfigured hero. He was replaced after extensive rehearsals but before opening night with the suggestion that 'the legacy of his polio ... caused doubts about his ability with the physical rigours of the part' (Cooper 2005, p. 48). Only in 2005, though, did Harley sing explicitly of his own childhood polio experience, in a slow heavy rock song called 'The Last Feast', which he has described as 'a primal scream ... remember[ing] pain beyond description after the [corrective] surgery' (quoted in Cooper 2005, p. 48). In fact the direct lyrical reference is largely confined to the chorus, in which the childhood memory of polio-induced paralysis is compared and contrasted with his current desired state of religious grace:

Sweet angels, open my eyes

I been dreaming I've been paralysed

Sweet angels, open my eyes

I been dreaming I'm in paradise. (Cockney Rebel 2005)

For some of the singers identified here, periods of treatment, and in particular stretches of residential rehabilitation that could effectively mean years of childhood institutionalisation, did also at least present the opportunity for entertaining with the voice. After all, the polio ward held a captive audience. 1960s pop singer Ray Peterson first began singing as a boy when he was undergoing treatment at President Franklin D. Roosevelt's famous Warm Springs hydrotherapeutic centre in Georgia, USA. Joni Mitchell's youthful singing was rather more protest-oriented.

I guess I really started singing when I had polio ... They said I might not walk again and that I would not be able to go home for Christmas. I wouldn't go for it. So I started to sing Christmas carols, and I used to sing them real loud. When the nurse came into the room I would sing louder. (quoted in Crowe 1979)

In the case of Israel Vibration, the fact of institutionalisation was formative for the group: separation from the majority effected a stronger minority identity, since the three original members met and began to sing with each other while they were long-term residents at the Mona Rehabilitation Centre, near Kingston, Jamaica. The three young men had several points in common: a passion for the close-harmony reggae singing popular at the time, an interest in Rastafarianism, and the experiences of polio and institutionalisation. Their first public performance was at the Theological College next door to the centre in 1974. When they left the centre, some other Rastafarians rejected them, seeing their impairments as a punitive sign from God (see Riverfront Times 1996). When performing live onstage the singers are able to stand and move around by use of their crutches, while on the cover photography of their 2002 album Fighting Soldiers, they pose with their walking aids in a rundown street. In one image, they hold the metal crutches like rifles and point them at the viewer - a mix of gangster and 'fighting' polio survivor. Occasionally Israel Vibration sing songs that resonate with their experience of impairment, while even the reggae accompaniment, with its characteristic and insistent offbeat rhythm and chords, seems suddenly more fitting for musicians with mobility difficulties, where a lilt is no longer so far removed from a limp. Song titles like 'Tippy Tippy Toes' and 
'Level Every Angle' emphasise the visual and sonic narrative of disability. It is not difficult to hear the latter as extending the fairly standard post-civil rights and post-Bob Marley rhetoric of one love reggae into a kind of disability rights context. So 'Level Every Angle' becomes at least in part Israel Vibration's plea for public spaces and design to consider the access requirements of mobility-restricted people, as they sing:

Some people are blessed while others are cursed ...

From every angle things should be level

And everything would be all right. (Israel Vibration 2002)

As we have seen, in Canada in 1951, both Joni Mitchell (aged nine years) and Neil Young (aged five) contracted the virus; in Young's case, as his father wrote at the time, overnight the child 'moved like a mechanical man, jerkily, holding his head in a tense position' (quoted in Rutty 1988, pp. 8-9). Home after a short period of hospital isolation, the boy told his father 'Polio is the worst cold there is' (quoted in ibid., p. 15). Young's polio impairment consists of 'a slight limp evident when he walks' (ibid., p. 25, n. 92). In Christopher J. Rutty's view, the 1970 Young song 'Helpless' contains his childhood memories of the experience of the disease. The song focuses on the moment, location and aftermath - both immediate and longterm - of the boy's contraction of the virus - and possibly also of the girl's, if we bear in mind a famous performance of 'Helpless' such as Young's in The Last Waltz film of the star-studded 1976 concert organised by The Band. Joni Mitchell features on backing vocals, the two Canadian polios on the same stage singing the same song about a shared past (Scorsese 1978).

There is a town in north Ontario ...

All my changes were there ... (Young 1970)

The title is also a kind of single-word chorus, and is repeated in groups of four by backing singers, including the fade-out at the song's end. Such a repeated state of helplessness captures the family moment, which is one of disease, uncertainty, dread, as well as perhaps some social shame, since 'The chains are locked and tied across the door'. Standard procedure by medical authorities to polio outbreaks in Canada and elsewhere (see Shell 2005, pp. 32-4) meant that Young would be isolated in hospital, while his family were subject to quarantine at home, his father remembering:

I was the only one ... allowed out ..., and only to buy groceries. The white quarantine sign greeted me every time I returned to the house ... the words on the sign 'Poliomyelitis. Infantile Paralysis'. (quoted in Rutty 1988, p. 10)

The high tremolo of both Young's voice and the guitar, and the melancholic fall of the voice at the end of most lines, contribute to the pathos of the situation described. Alongside the lyrics, Young's falsetto-style vocal delivery also takes the listener back to a boy's childhood ("the prevalence of "high" voices in rock music can be seen ... as an associative marker of "youth"'; McLeod 2001, p. 201, n. 2), sounding out the point that the voice is not yet broken, but the body may already be. Such a straining or forcing to a higher register as here also begins to move towards Laurie Stras's notion of the 'damaged voice' (Stras 2006, pp. 179-83); this is a post-Barthesian reading of the 'grain' which would develop Barthes's privileging of the imperfect in the body-voice relationship into the context of the disabled body in pop. The appearance of male falsetto in popular music readily connotes high emotion, queerness or campness in musical styles from soul to disco (see Wise 2007), while 
rock's 'fascination with high-register male vocalists' may indeed transmit 'a sense of transgression ... of the bondage of social norms and conventions', as Ken McLeod argues (McLeod 2001, p. 190), but it also confirms certain masculine and corporeal normativities. Via Young or indeed Robert Wyatt, another disabled singer who employs a high-register delivery in a sustained way in his vocal performance, a potentially different, more partial and vulnerable, relation between the male body and voice is sounded. Thom Yorke hears in Young's 'soft vibrato', for instance, a man 'singing in that register, in that frail way' (quoted in Cooper 2008, p. 19; emphasis added). This quieter falsetto is employed and understood as the sound of 'sensitivity' (Young's word: quoted in Cooper 2008, p. 21) and introspection. In Tim Wise's view, the introduction of a high voice into a song can suggest 'frailty or loss of control', and 'because it often occurs in singers presenting a sensitive nature (for example, Joni Mitchell ...), we tend to hear this break as indicative of the fragile personality near the breaking point' (Wise 2007, p. 44).

\section{Ian Dury: 'the way the cripple crumbles'}

The stereotype of the 'flawed' artist remains as strong as ever within western culture. Post-punk singer Ian Curtis, of the cult rock band Joy Division, for example, owed some of his reputation for tragic extremism to his epilepsy. But while impairment may on occasion be said to add to the appeal or the insight of a particular artistic figure, it is important to remember that many artists with accredited impairments have denied or ignored this aspect of their lives. Others have reacted in a personal rather than a political way. Contemporary examples include musicians Ray Charles, Jacqueline du Pré, Evelyn Glennie, Stevie Wonder, Hank Williams and Ian Dury. (Colin Barnes 2003, pp. 7-8)

I want to take issue with the last named by Colin Barnes here. It is my argument that in fact Ian Dury, that 'flaw of the jungle', produced a remarkable and sustained body of work that explored issues of disability, in both personal and social contexts, institutionalisation, and to a lesser extent the pop cultural tradition of disability. He also, with the single 'Spasticus Autisticus' (1981), produced one of the outstanding protest songs about the place of disabled people in what he called 'normal land'. Jim Drury makes the passing observation that, as Dury's career developed, 'he began singing more frequently about life as a disabled person' (Drury 2003, p. 95), but such a trajectory is I think extremely unusual for pop musicians.

The music business could be nervous about pop engaging directly with disability, though. One of Dury's managers, Peter Jenner, sensed that his disabled body was a significant turn-off for the major record companies. In fact, in his pre-punk career Dury had once been judged 'unsuitable for stardom' by CBS A\&R department (Muirhead 1983, p. 17), while even the professional chaotics at the punk-era Stiff Records could be nervous about telling the truth about one of their biggest stars. Dury's decision to appear in the video for the chart-topping single, 'Hit Me With Your Rhythm Stick' in 1979 without a jacket - hence displaying his withered arm - what the video's producer understood as Dury's act of 'com[ing] out about his disability' - sparked a panic at the record company (see Balls 2000, p. 203). He sang on 'Spasticus' that 'You can read my body but you'll never read my books', yet the texts he produced, his song lyrics, were a compelling counterpoint to a straightforward, or inescapable, reading of his body. Sometimes, his body was his book, as he wrote autobiographical and observational lyrics about disability, and then performed those stories on stage (see Figure 4). 


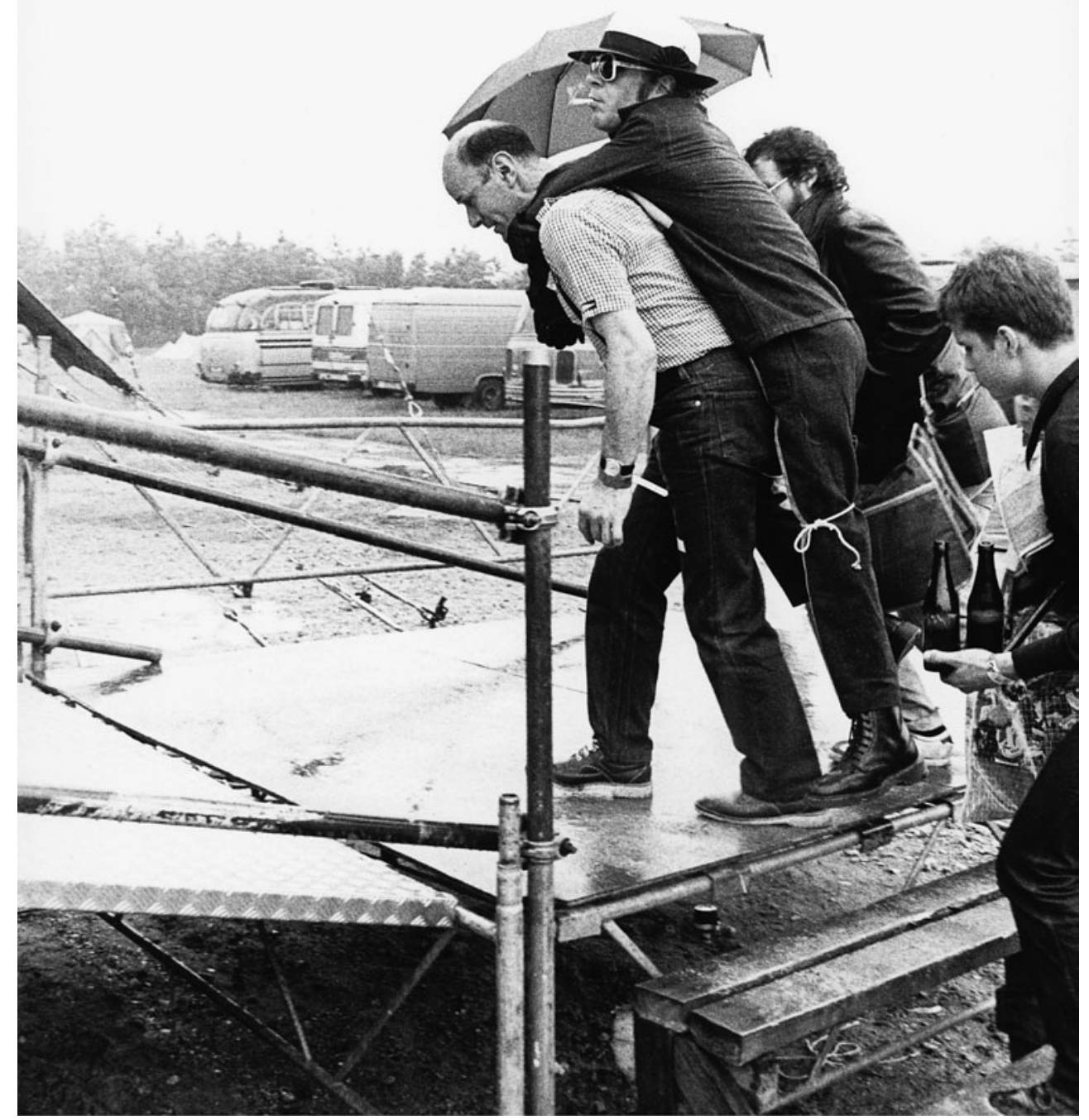

Figure 4. Ian Dury being lifted on stage at a festival, Denmark, early 1980s. (C) Photographer Jorgen Angel / Redferns. Used with permission.

In the summer of 1949, aged seven years, Dury contracted polio in an open air municipal swimming pool in Southend. He spent the next eighteen months in Black Notley Hospital, Essex, in a ward full of seriously ill and disabled children, and then transferred for three-and-a-half years to the residential Chailey Heritage Craft School and Hospital in Sussex, described by its founder Grace Kimmins in 1903 in the language of the time as 'the public school of crippledom', located in an old workhouse building, with origins in the Victorian Guild of the Brave Poor Things (Borsay 2005, p. 108; see also Balls 2000, pp. 35-6). Some of Dury's songs from the height of his success draw directly on his own medical autobiography, in particular those five childhood years of institutionalisation. The lyrics of 'Dance of the 
Screamers' (Dury 1978) show him consciously speaking on behalf of 'the screamers' - people with disabilities, imperfections, the marginalised and misunderstood, the kind of people who are doubly cursed, because they 'went and missed the end bit' of the show, 'but we never quite caught the bus' - and addressing the normals, in a genre of music described by co-writer Chaz Jankel as 'punk jazz'. The lengthy fading coda of Dury's vocal screams, plus the upper register free-form harmonics of Davey Payne's distorted saxophone, takes Dury towards what one of his musicians describes as an 'unbearable' sonic territory. This pop makes even the musicians in the studio 'wince', for it is 'painful' and indeed even 'deafen[ing]' (see Drury 2003, pp. 94-6). Underpinning 'Dance of the Screamers' is his memory of intensive physiotherapy at Black Notley, which he spoke about in numerous interviews: 'It was called the screaming ward and you could hear people screaming on the way there, and it was you when you was there, and you could hear the others on the way back' (quoted in Gould 1995, p. 231).

By the 1950s, Chailey was a National Health Service residential school and hospital for children with disabilities, and severe deformities, based around an austere ethos of fostering independence - the success of which Dury acknowledged in later life: 'Chailey made me strong physically and mentally', he said in 1999 (quoted in Balls 2000, p. 43). Combined with this, though, was some stark discipline, which, in Dury's memory, segued into institutional violence - between children and by carers. On top of this, Dury recalled sexual abuse: 'A lot of the staff were pervs. No buggery, but a lot of enforced wanking' (quoted in Balls 2000, p. 36). What is confirmed in his experience from the 1950s is a longer-lasting practice of physical and psychological abuse within British residential special schools, as Anne Borsay has outlined:

Some special schools were brutal with harsh discipline and living conditions reminiscent of the workhouse ... [They] failed to react appropriately to their pupils' emotional responses, shaming them into the repression of feelings about impairment and family separation ... The significance of disability was also denied. Schools made strenuous efforts at 'normalization' by experimenting with new aids and appliances. Their staff mocked the academic abilities of pupils and their capacity for personal care. (Borsay 2005, p. 114)

It is highly likely that Dury's most compelling and harrowing song about the institutionalisation of disabled people, 'Hey, Hey, Take Me Away', from the 1980 album ironically titled Laughter, draws on his experiences of life at Chailey.

Hey, hey, take me away

I hate waking up in this place

There's nutters in here who whistle and cheer

When they're watching a one-legged race

And a one-legged prefect gets me in bed

Makes me play with his dick

One-legged horn and he's shouting the odds

Driving me bloody well sick. (Dury 1980)

Dury's opening vocal scream and Payne's saxophone harmonics are reprised from 'Dance of the Screamers' for the supply of emotional intensity and disturbance, but there is so much more in this one short (under two-and-a-half minutes) song - as well as a clear distantiation from other disabled people ('I hate waking up in this place'). Lyrically, co-writer Mickey Gallagher remembers it from the recording sessions as 'the song that shocked everybody' (quoted in Drury 2003, p. 120). It covers masturbation, adventures of escape, sexual abuse, physical violence by carers, physical violence between children, the fear of and disgust at the disabled 
body or mind, suicide, self-loathing, the yearning to be 'normal' ... Dury's delivery moves between spoken word, angry and rushed shouting and swearing, and a pathetic sobbing that is sometimes a whisper. Gallagher heard in this crying Dury's familiar 'best acting voice, which he probably developed as a boy in those institutions, to get people on his side' (quoted in Drury 2003, p. 122). The editing of the voice tracks is extraordinary and sometimes brutal, and contributes powerfully to the song's confusion, discomfort and fright: one can hear the joins, sense the edifice, feel the effort needed to hold it together. Some of Dury's words are spliced out half-way through, odd sentences make no sense, he runs out of time towards the end as the pre-recorded music runs away from him, he misses a cue and speeds his words both to catch up and to fit the remaining bars.

Gallagher recognises Dury's 'best acting voice' in 'Hey, Hey, Take Me Away', while Dury himself articulated in 1973 something similar about being effectively institutionalised at Chailey.

Being in that place is one of the reasons I talk the way I talk. Before that I talked not quite BBC. A third of the kids there were funny in the head as well as being disabled ... The situation was that from within you got very strong, but also you got coarsened ... There was a lot of behaviour that just don't happen in the outside world. Later you pretend to be arty about it but when I was there, I was just there, it was real. Thinkin' about it now, I realise it was fuckin' heavy. It was like a hospital in one way, like a school in another way, and like a prison in another way. (quoted in Balls 2000, p. 40)

Here is evidence of the blurring of performative strategies between being disabled and constructing a persona that would be attractive on stage, as in life - the über-Cockney banter of the self-styled 'Upminster kid' or Lord Upminster, as Dury song and album titles put it (from a middle-class grammar school boy). It was the 'coarsened' Dury that offered to the world his shocking (even in the punk context of 1977) short unaccompanied spoken introduction - rhythmic, like a tabu count-in - to the song 'Plaistow Patricia', from New Boots and Panties: 'Arseholes, bastards, fucking cunts and pricks' (Dury 1977). Intriguingly, like Dury, Steve Harley was another faux East Ender in vocal delivery and image, with his 1970s band Cockney Rebel: could cultural 'coarseness' be a compensatory catch, a way of linguistically toughening out for these performing polios? It's one of the male routes open to the talking crip. Rosemarie Garland Thomson has reminded us that:

To be granted fully human status by normates, disabled people must learn to manage relationships from the beginning. In other words, disabled people must use charm, intimidation, ardour, deference, humour or entertainment to relieve nondisabled people of their discomfort. Those of us with disabilities are supplicants and minstrels ... (Thomson 1997, p. 13)

If we follow the Dury template strictly, we must acknowledge that those of us with disabilities are wind-up and fuck-off merchants, too, the kinds of performers 'who use excess and destabilisation in order to move beyond the difference-denying polite frameworks of asinine sameness' (Kuppers 2003, p. 47; see also, for other musical examples, Colin Cameron's article in this special issue). Dury presented a cluster of masculine identities - the music hall cheeky cockney à la Max Wall (interestingly, renowned for his visually excessive walking) or Max Miller, the elder punk dandy, the bohemian art school jazz buff, the frank raconteur of disability, for instance. His biographer Richard Balls described his 1977 performances as offering a stage persona and costume that ranged from Bill Sykes to the Pearly King to Tommy Cooper (Balls 2000, p. 177). There was also in his writing an approach to 


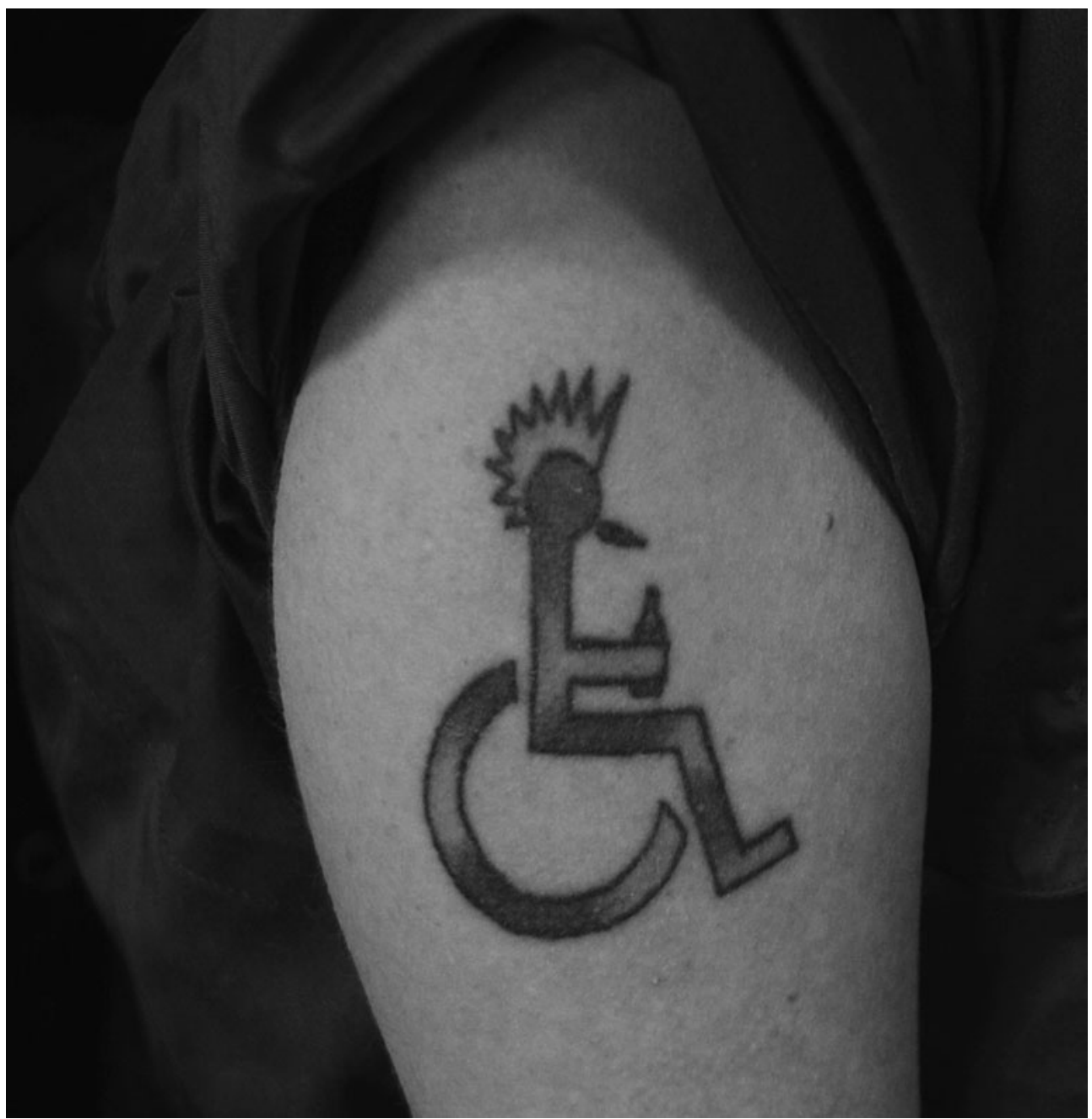

Figure 5. Disability, identity, the body, subculture: a disabled punk's tattoo. (c) Photographer Jessy Franklin 2008. Used with permission.

sexuality (and not simply heterosexuality) that told stories ranging from tongue-tied fancying to tongue-twisting sexual acts. The socialist writer David Widgery, who was himself a polio survivor, has explained: 'That's why I found Ian Dury so emancipated. Suddenly there was this sex symbol who had a limp' (quoted in Gould 1995 , p. 250). On the other hand, a problem with Dury as a cultural representative of disabled people may have been his dirty old man in a mac persona - that in a way he confirmed for what he called the 'walkie-talkies', the inhabitants of 'normal-land', and what other disability activists have called the TABs (temporarily able bodied), something distasteful, dangerous, deviant, sexually threatening within, even inherent to, people with disabilities.

Some music-centred subcultures have opened up new cultural spaces and corporeal expectations (see Church 2006 for a discussion of the 1960s hippy 'freak' identity in the context of disability). In particular, punk and post-punk enfreakment 
were early embodied in the staring, semi-hunchbacked Sex Pistols singer Johnny Rotten (both eye and spine permanently affected by childhood meningitis, ${ }^{9}$ while his pseudonymous surname was in reference to the poor state of his teeth). Jon Savage (another pseudonym) documents how, at an early gig in 1976, Rotten improvised a song introduction:

Right!

Here we go now

A sociology lecture

A bit of psychology

A bit of neurology

A bit of fuckology

No fun! (quoted in Savage 1991, p. 156; emphasis added)

Versions of the body would figure centrally in the work of the Sex Pistols, from the band's name to the title of their one album, Never Mind the Bollocks, which contained a song called 'Bodies', in which Rotten tells us repeatedly that 'I'm not an animal' (Sex Pistols 1977). Punk dwarves graced the shop floor of Vivien Westwood and Malcolm McLaren's King's Road boutiques, while bands with names like the Epileptics (UK), Disability, or the Cripples (both USA) made minor provincial waves. The punk audience's style of anti-dancing, the pogo, and its preferred practice of greeting bands onstage by spitting or 'gobbing' at them, signal corporeal non-conformity or excess. Dick Hebdige describes some of the features of punk that manifested themselves during and after the 'freak disorder' of 1976, including dance that consisted of 'twitches of the head and hands or more extravagant lurches', as well as 'the ECT hairstyles' (Hebdige 1979, pp. 24, 109, 121). According to Marc Bayard, 'the early days of American hardcore' punk were populated by 'freaks and misfits' (Bayard 1999, p.6). The wonderful tattoo sported by a contemporary American punk and wheelchair-user in Figure 5 displays the continuing appeal of subcultural identity for some pop fans with disabilities. My own punk experience was partly informed by my own body, my own medical autobiography, as I rediscovered recently when I dug out an old piece of writing about the subject.

\section{BODIES}

I'm learning a new way of walking too, there really is that in punk, a sort of spastic lope I'm quite good at ... Childhood memories of blood tests and biopsies in hospitals north and south of the border, and lying next to the Scottish boys in their iron lungs. Let's see those legs, young man. Trip up a lot, you say? I never knew my suspected dystrophic muscles would ever actually come in useful. If something like that can be a bonus, punk's the subculture for mee-ah! (McKay [n.d.]; italics original)

To what extent did the punk aesthetic of the later 1970s make it possible for someone like Dury to find mainstream success? One of the clutch of blazing reviews of the groundbreaking Stiff Records package tour of 1977 described Dury as 'the most scandalous and hilarious anti-hero to have emerged in the year of punk' (see Figure 6). In another, BBC Radio 1 DJ Annie Nightingale saw Dury as embodying the shift in rock music that punk was claiming: 'Rock's latest hero is the very antithesis of the stereotype, flamboyant, aggressive sex symbol. Dury is 35 and still semicrippled by polio which struck him at the age of seven. The walking stick he uses on stage is no theatrical prop' (quoted in Balls 2000, pp. 183, 182-3). Yet Dury's career pre-dated punk. His founding band Kilburn and the High Roads (1971-1976, with various line-ups) relied heavily through the pub rock scene of the times on a visual 


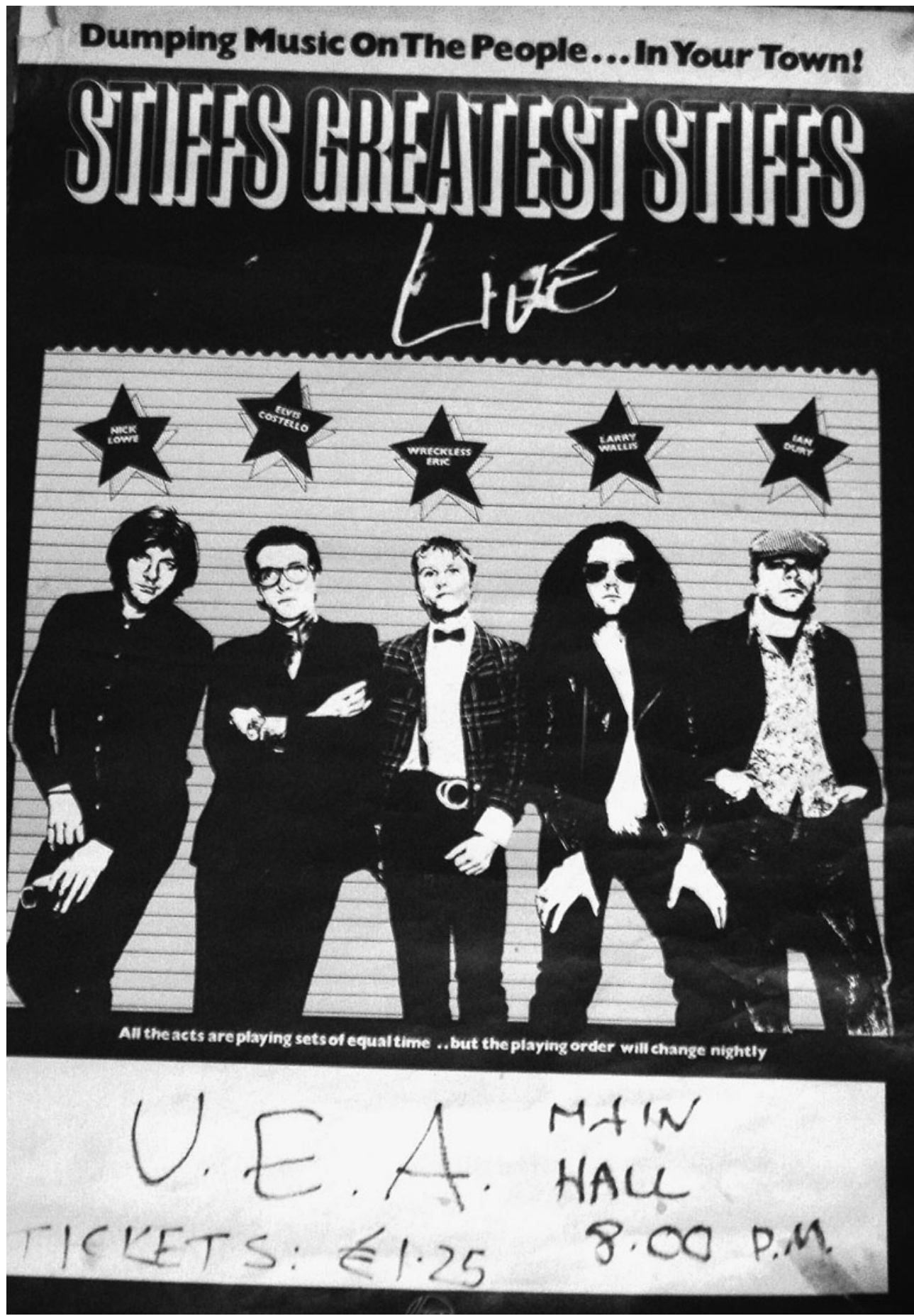

Figure 6. Stiff Records package tour poster, 1977, Dury far right: 'the most scandalous and hilarious anti-hero to have emerged in the year of punk'. Author's collection. 
distinctiveness predicated on freakery. As New Musical Express neatly encapsulated it in 1975, the Kilburns were

composed almost entirely of demobbed cripples in chip-stained Dannimacs and vulcanised slip-ons. They all had short hair - badly cut and partially grown out like ex-cons. They had a bass player ... who was nearly seven feet tall, a black drummer who had to be lowered manually onto his drum stool[,] and a lead singer with a stiff leg, a face like Gene Vincent, and a withered hand encased in a black glove. (quoted in Drury 2003, p. 15)

Later Kilburns members recognised the arresting visuality of their own freak show or circus troupe aesthetic - mandating not the gaze but the stare, in Thomson's distinction (see Thomson 2000). When 'midget' (Dury's word) bassist Charlie Sinclair joined, he experienced what Dury called the 'certain outcast thing' the band embodied and presented as their show.

People would just stand and stare. They would just crowd around the stage and gawp most of the time. It was probably quite a frightening thing for some people. At the time it was all glam rock, but there was none of that with us. It was just a bunch of guys you would see on a park bench with a can of Super Lager or something. It really did look like 'care in the community' some days. It was disturbing visually. (all three quotations in Balls 2000, p. 119)

Some pop disabilities are among those which, like the freak shows of nineteenth-century USA, could offer 'a counternarrative of peculiarity as eminence' (Thomson 1997, p. 17), in which 'enfreakment' could mean authenticity, authority, even status. Also, though, unlike other more contemporary popular manifestations of the relocated 'freak show', from the television talk show guests to bodybuilders to Michael Jackson in his 'Wacko Jacko' period as discussed in Thomson's collection Freakery, for instance (see Thomson 1996, part VI), the Kilburns seemed to pose an actual threat to audiences. As Sinclair acknowledges, they were perceived as 'frightening' and as 'disturbing', and that was the audience reaction they aimed for. The uncompromising visual image and attitudinal stance were key aspects of the Kilburns's stage practice which spoke to the punk generation about to be waiting in the wings.

Seeing Dury onstage with the Kilburns in the early 1970s, reviewers frequently compared his pose to that of the then recently deceased American rock ' $n$ ' roll singer Gene Vincent, as well as noting his use of the microphone 'as if it was some form of surgical apparatus' (Time Out), - 'Either he was propping the mike stand up or it was keeping him upright' (Melody Maker) (see Balls 2000, pp.105-6). Of course, Dury would also pay homage to Vincent in his songs, in particular 1977's 'Sweet Gene Vincent'. Vincent's performances of disability in black leathers and flaunted limp (from at least two road traffic accidents) were central to his British stage and television acts. New Musical Express reported on his British debut in December 1959: 'In spite of an old leg injury which has left him slightly lame, Vincent performs miracles with the mike stand ... Add a peculiar half-crouching stance, and his act ... was [as] exciting to watch as it was to hear' (quoted in Heslam 1992, p. 75). Dury talked in 1973 about Vincent's impact on him as a young fan in the 1950s and 1960s.

Gene Vincent got to me more than anybody; he was in a special little category because he was what I wanted to be as a singer. I didn't know he was crippled at the time, so that didn't have anything to do with it. It was his head, the shape of his head, because it was opposite from mine ... It was his thinness, his wastedness. (quoted in Balls 2000, p. 54; italics added)

This remark dates from before he had written 'Sweet Gene Vincent', the lyrics of which acknowledge Vincent's physical frailty and disability ('lazy skin and ashtray 
eyes ... But your leg still hurts') - and yet even here Dury the pop fan is evaluating and articulating his musical enthusiasms within a corporeal framework. It is Vincent's body, the way it moves and is held in performance, as well as the 'sad Virginia whisper' of his voice, that matters to Dury, and that he wants to emulate (Dury 1977).

So, it is arguable that Dury and the Kilburns's pre-punk performative strategy influenced the punk aesthetic of imperfection, rather than Dury's success being explained by the sonic, visual and corporeal shift that punk may, or claimed to, have caused. At the final Kilburns concert in London in 1976, one of the support acts was the Sex Pistols. Dury recognised with some concern in Johnny Rotten's clothing, bodily performance and vocal delivery his own act, by a younger singer for a new generation of audience. He turned to the Sex Pistols's manager Malcolm McLaren and said 'What's all that about, Malcolm? He's copying me, isn't he?' (quoted in Balls 2000, p. 143). The extraordinary contumacious body of young punk Rotten was drawing on the same of old punk Dury, but then Dury had been doing it for years with the Kilburns anyway, and also drawing on the imperfect rock ' $\mathrm{n}$ ' roll body of his own youth in Gene Vincent. Compellingly there is a strand of disabled cultural identity running through and connecting these three musical figures, these generations, with Dury at the centre of it.

\section{'Spasticus Autisticus': the impossibility of functioning}

My awareness within the record of 'Spasticus' wasn't a shared awareness amongst 'walkietalkies', so I obviously knew there was a risk that I was going to alienate a lot of people and they were going to get the hump with me, [saying] 'What's this fucking spazzer doing moaning?' Well I wasn't moaning, I was actually doing the opposite of moaning. I was yelling. (Ian Dury, quoted in Drury 2003, p. 131)

As a global consciousness-raising exercise, the United Nations declared 1981 the International Year of Disabled Persons. Recorded in the Bahamas (without his usual backing band, the Blockheads, but with leading reggae musicians Sly Dunbar and Robbie Shakespeare) the song, and the single (his first for his new, more commercial label Polydor), 'Spasticus Autisticus' was Dury's public response to a public gesture. In this song there is I think an extraordinarily powerful - not only within the context of the pop world - 'narrative of corporeal otherness ... [presenting] the disabled figure's potential for challeng[e]' (Thomson 1997, p. 16). In fact, his motivation for the song, and his understanding of his own position as a public figure of disability, was complex. One idea was to 'get a band together who were either recruited from mental hospitals or recruited from really savagely disabled places' (Dury, quoted in Polydor 1981). Instead, he explained, he wrote a 'war-cry':

The Year of Our Disabled Lord 1981 I was getting lots of requests. I turned them all down. We had this thing called the 'polio folio', and we used to put them in there... Instead I wrote this tune called 'Spasticus Autisticus'. I said, I'm going to put a band down the road for the year of the disabled; I'll be Spastic and they can be the Autistics. I have [my band named the] Blockheads and that means they're autistic anyway. And my mate goes, 'No - Spasticus Autisticus, the [rebel] slave'. Great, I'm Spartacus. So I wrote this tune ... [I]t wasn't allowed to be played anywhere and people got offended by it - everybody except the spastics. (quoted in Gould 1995, p. 253)

As he notes, the politics of self-naming (as Figure 7 shows, for audience members too) is evident in the flaunted stupidity of calling his backing band the Blockheads 
(after one of his song titles) though before settling on that name he was considering 'Cripple, Nigger, Yid, Chink \& Dead Fish. Easier to say than Dozy, Beaky, Mick \& Wotsit, innit?' (quoted in Balls 2000, p. 185). As a boy, when he left Chailey to attend grammar school, Dury was bullied, called 'Spastic Joe' by other boys, and forced to wear shorts (which displayed his heavy iron leg calliper) for the first year. Of course, 'Spasticus' was also a cultural effort at what Brendan Gleeson has termed 'the reappropriation and revalorisation by disabled people of abject terms for impairment' (Gleeson 1999, p. 136). This view is taken by Nancy Mairs, who has written that people

wince at the word 'cripple' ... Perhaps I want them to wince. I want them to see me as a tough customer, one to whom the fates/gods/viruses have not been kind, but who can face the brutal truth of her existence squarely. As a cripple, I swagger. (quoted in Thomson 1997, p. 25)

We have seen that Dury was happy to use language and even to produce music that could make people 'wince', not least (though not only) when he wrote songs about disability. But the lyrics of 'Spasticus' are not sprinkled with the swear words so common elsewhere in Dury's oeuvre; much of their power comes from their startling simplicity, as here describing bodily imperfection and malfunction or mobility difficulties.

I widdle

when I piddle

'cos my middle

is a riddle ...

I'm knobbled

on the cobbles

'cos I hobble

when I wobble. (Dury 1981)

Yet the BBC did indeed ban the song (in fact the corporation had previously banned the 1977 Dury single 'Sex \& Drugs \& Rock \& Roll', so he did have a track record of controversy which perhaps undermined his stated serious intent with 'Spasticus'), though only until a 6 p.m. watershed, a decision which itself irked Dury. His record label subsequently sought to strike a defiant as well as sophisticated note regarding the record's failure to chart, releasing a statement which said: 'Just as nobody bans handicapped people - just makes it difficult for them to function as normal people - so "Spasticus Autisticus" was not banned, it was just made impossible to function' (quoted in Balls 2000, p. 240). There were also protests about the song from the primary British charitable organisation responsible for the support and care of people with cerebral palsy, then known as the Spastics Society. Rather than a musical act of self-empowerment and the reclamation of abject terminology by a high profile disabled artist, the Spastics Society heard a controversial singer confirming by aggressive repetition in the song's chorus the common playground insult. ${ }^{10}$ On an Australian tour in 1982 the authorities in Brisbane threatened to have Dury arrested if he played 'Spasticus' live; of course he did it anyway. It is notable that a major part of the afterlife of 'Spasticus' is in the context of its (partial) censorship: in the 1990s it appeared variously on a CD included with an Index on Censorship special edition entitled 'The Book of Banned Music' (1998), and on a Channel 4 television documentary on the top-ten banned records in popular music history. Debatably its removal from the 'polio (or disability) folio' to be stored in the censorship file is one more act of making it 'impossible to function'.

As his first single since leaving the independent Stiff Records for the major label Polydor, it was a provocative, or self-destructive, choice. In fact we can and 


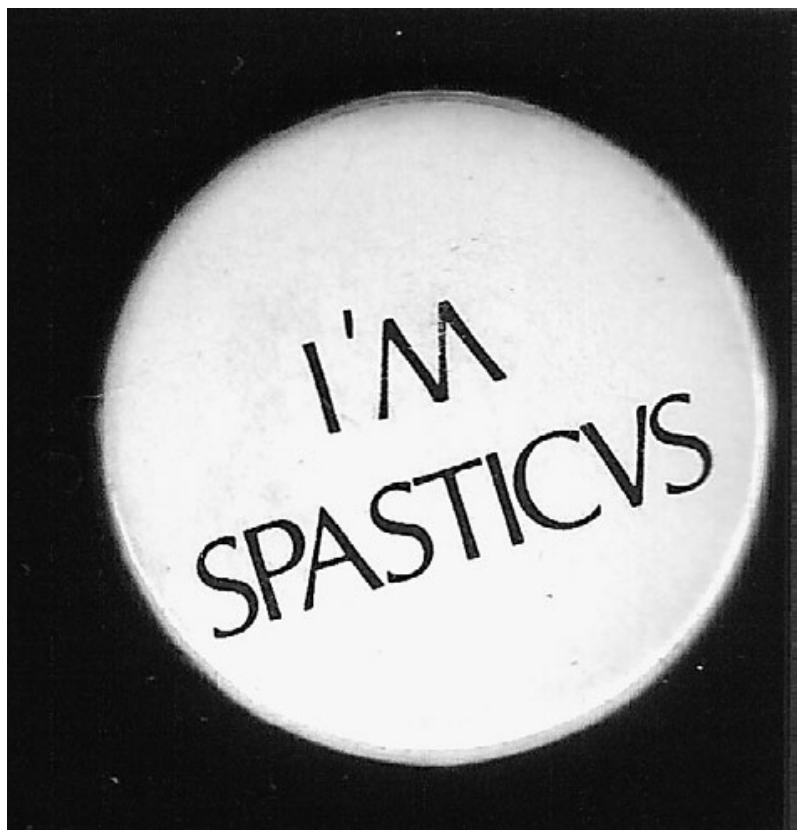

Figure 7. 'The politics of self-naming': Dury lapel badge for 'Spasticus Autisticus' single, 1981. Author's collection.

should go further - to release it as a single (let alone that it was on a new label, and with a new band) was an extraordinary, and brave, if also frankly career-shattering move on Dury's part. A dance-rhythm pop song about spastics, released as a single, with a political message and a powerful and discomforting accusation? The press release accompanying the single contains a section entitled 'No handicap', and locates the song firmly within Dury's childhood experience, in a section headed 'About polio' (Polydor 1981). Yet in other ways it is the song that most departs from polio and from Dury's medical-musical autobiography towards a much more general and encompassing position. This is clear from the propagandising text included on the picture sleeve, in which the character Spasticus, a politicised Psychomodo, explains his purpose:

I COME AMONG YOV AS AN EXAMPLE

SENT BY MY TRIBE TO PORTRAY THEM

AS THEY ARE, AS BEAVTIFVLLY AS I AM, IN ALL MY GLORY...

THE EXTREME MEMBERS OF MY TRIBE ARE KILLED AT BIRTH.

WITHOVT THE AID OF OTHERS MY TRIBE CAN ONLY CRAWL

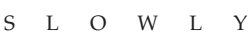

HALlo to YOV OVt THERE IN NORMAL LAND. (Dury 1981; typography original)

To conclude, with the song 'Spasticus Autisticus' the polio and pop generation I have charted and discussed moves most powerfully and demandingly outside its own cultural and corporeal concerns to challenge and to populate a wider, more ambitious territory - the entirety of Normal Land. Critics confirm for us the power involved, as popular music's infectious nature extends the discourse of disability. In a 1962 review of the radio ballad The Body Blow, the Sunday Telegraph caught the neuro-muscular condition: 'I doubt whether a listener with full attention on this 
programme can avoid sympathetic agitation in his own muscles. At a playback for the press last week we all had trouble breathing' (quoted in Cox 2008, p. 126). A more excitable piece from the pop press in 1973 described Dury's band Kilburn and the High Roads in terms of impairment, or corporeal defect: 'Dancing to the Kilburns is like being on the verge of shitting your pants and enjoying it! You can't stand still so you jerk around uncomfortably for a while, then you develop a system of easy flowing constant motions to keep your bowels from evacuating' (quoted in Drury 2003, p. 16). How should we read that generation's cultural work overall? It is in part an achievement, the familiar and comforting disability narrative of overcoming, which draws on isolation or instrumental training as therapy as routes towards expression. Here we have seen that songs of childhood memory are not innocent or idyllic, but painful, scar(r)ed, and angry. Nor is overcoming always comforting, and the rejection of victimhood here is sometimes uncompromisingly stated. It is a performance, which capitalises on popular music's intermittent capacity to value images of deviancy or enfreakment. Here related subcultural styles and attitudes can contribute acceptability and access. It is too a political act, of advocacy, consciousness-raising or campaigning. Musical approaches vary: there are the adaptive instrumental techniques employed by some musicians (Joni Mitchell, Carl Perkins, Horace Parlan), the damaged grammar of self-styled Cockney Rebel Steve Harley, even the potentially alla zoppa reggae of Israel Vibration. ${ }^{11}$ That generation's music may be part of pop, but it needs to be acknowledged that it can seem quite unpopular: CeDell Davis with his 'out of tune' guitar-playing, the 'damaged voice' of Neil Young's song of polio and experience (or, earlier, the non-musicality of Connie Boswell's singing, as explored by Laurie Stras elsewhere in this special edition), Dury with his 'deafening' screams and the single that bombed and was banned, for instance. My aim has been to uncover and explore the polio and pop generation, and to show how the work of Ian Dury sits at the impressive heart of it. That most public of his songs about disability, 'Spasticus Autisticus', closes with a number of male and female, normal and impaired voices proclaiming each in turn 'I'm Spasticus'. ${ }^{12}$ I have argued that the song is directed outwards, to the inhabitants of Normal Land, as a piece of cultural advocacy. But it is also directed inwards, in its closing collective gesture of self-identification and empowerment. To achieve both, in a single pop song, makes it in my view a compelling challenge to what Marc Shell (2005) has termed the 'the paralysis of culture' that surrounds polio survivors.

\section{Acknowledgements}

I owe thanks to Steve Harley for some initial discussion of this work, to Tony Gould for the transcription of his 1991 Ian Dury interview, to Peter Cox for sending me a transcription of his interview with Peggy Seeger about The Body Blow, to Christopher J. Rutty for sending me a copy of his Neil Young 'Helpless' essay, and to Jessy Franklin and her brother Sean for the tattoo photograph. Also to Petra Kuppers, Neil Foxlee, Tony Whyton, Les Back, Gareth Palmer, Tim Wise, and the journal reviewers, for critical or musical suggestions.

Versions of this article have been presented at Lancaster University Institute for Cultural Research research seminar (2006); Vytautas Magnus University, Kaunas, Lithuania, Society and Lifestyles project meeting (2006); Salford University Postgraduate Conference on Authenticity keynote lecture (2006); Liverpool John 
Moores University Cultural Disability Studies Research Network keynote lecture (2007); Warwick University Transnormative Cultures symposium (2008). Thank you for the invitations and the organisation. Also I am grateful for a University of Sydney International Visiting Fellowship in 2008, which enabled me also to talk about the work at Royal Melbourne Institute of Technology, Griffith University, Brisbane, and University of Technology, Sydney.

\section{Endnotes}

1. In respiratory centres in 1950s' USA, groups of young ventilator-dependent polio survivors often produced mimeographed newssheets. Referencing the 'rocking' technique of physical movement recommended to aid artificial breathing for some, newssheet titles reflected youth and pop music tastes of the time: The Rocking Reporter, The Rock ' $n$ ' Roll (Gould 1995, p. 194). This is cited as small evidence of the generational coincidence of (late) polio and (early) pop.

2. Compare figures for the scale of the disease elsewhere: in the 1980s in the USA there were over 600,000 polio survivors, and in India an estimated 12 million (Gould 1995, p. 223).

3. Some early vaccinations malfunctioned, and infected the patient with the disease. This happened to folk singer Donovan as a boy in Scotland: 'The vaccines were too strong, and I was actually given the polio disease this way. So my right leg began to show signs of "wasting". An operation was performed, cutting the Achilles tendon in the foot, and I wore an ugly leg brace for some time after' (Leitch 2005).

4. For further reading, see Laurie Stras's various work on Boswell, including her essay in this Special Issue.

5. I keep qualifying in this way because polio nowadays is primarily framed within medical history in the developed world, as a problem which was resolved half a century ago by successful mass vaccination programmes (though Shell 2005, chapter 9, p. 204, challenges such easy historicising, asking 'What can we (still) learn about polio?'). An international eradication effort in the decades since has led to the virus being active in only three countries today.

6. The previous year MacColl and Seeger had written and sung songs about polio survivors for a thirty-minute television feature entitled Four People, which in fact used 'virtually the same subjects' for interview as the later radioballad (Cox 2008, p. 121).

7. Though not all jazz instrumentalists sought to make musical capital from their condition some viewed their polio experience as inspiring a different future career path. Saxophonist Dave Liebman: 'I had polio when I was young and was always around doctors. I wanted to be an orthopaedic surgeon' (quoted in Mandel 2003). Yet even Liebman has understood his music-making in the context of his disability: 'I feel strongly that the artist has a responsibility to look back. To get back to the roots ..., [T]here's no question that the need to play is based, say, on a difficult childhood. In my case I had a bad leg from polio' (quoted in Schermer 2008). For Charlie Haden, coming from a country music family in which he was a wellknown local child singer, his polio experience at the age of fifteen affected his facial and throat nerves and muscles, which meant the end of his singing career, but a focus instead on his instrumental career on the double bass (see Davis 2000). Nonetheless for Haden, the childhood polio is framed by the music shift, as he explained in 2006: 'I don't sing now, because I had polio when I was 15 , bulbar polio. This [c. 1952] was when the epidemic was happening. And I was lucky that it didn't affect my lungs or my legs. It went to my face and kind of paralyzed my vocal chords, and I wasn't able to sing' (quoted in Goodman 2006).

8. Dury songs that reference or explore disability, impairment, and/or institutionalisation in some way include 'Crippled with Nerves' (1975), Sweet Gene Vincent', 'Blockheads', 'Clevor Trever' (all 1977), 'What a Waste', 'Dance of the Screamers', 'Inbetweenies', 'Mischief' (all 1978), 'Hit Me With Your Rhythm Stick' (1979), 'Hey, Hey, Take Me Away', 'Dance of the Crackpots', 'Manic Depression (Jimi)' (the 'cripple crumbles' and 'flaw of the jungle' lines are from this song), 'I Want to be Straight' (all 1980), 'Spasticus Autisticus', 'The Body Song' (both 1981), 'Geraldine' (1998), 'Poo-poo in the Prawn' (1992), 'Drip Fed Fred' (with Madness, 1999).

9. In his autobiography, Rotten, the Sex Pistols singer explains: 'I was in a hospital for a year from age seven to eight ... They would draw fluid out of my spine ... it's curved my spine. I've developed a bit of a hunchback. The [Rotten] stare is because I developed bad eyesight, also as a result of the meningitis' (Lydon 1994, p. 18).

10. It is interesting that the Spastics Society has been no more successful than Dury in overcoming the stigmatised meaning of the word 'spastic' in everyday parlance; today the organisation has rebranded itself as Scope.

11. Alla zoppa: a musical term meaning "“limping" or "halting" in Italian ... this rhythmic figure is 
part of the instrumental tradition of representing physical impairments' (Lerner 2006, p. 88, n. 17). In this context, alla zoppa invites us to reconsider reggae's characteristic off-beat rhythm guitar and keyboard, as well as its sometimes out-of-time echo dub practices, as less lilt, more stilt.
12. This is of course a reworking of the famous scene in Stanley Kubrick's 1960 film Spartacus, in which the surviving rebel slaves announce en masse to the Roman authorities searching for the rebel leader that 'I'm Spartacus' (see Kubrick 1960).

\section{References}

Balls, R. 2000. Sex E Drugs E Rock ' $n$ ' Roll: The Life of Ian Dury (London, Omnibus)

Barnes, C. 2003. 'Effecting change: disability, culture and art?' paper presented at Finding the Spotlight conference, Liverpool Institute for the Performing Arts, Mav, http://www.lipa.ac.uk/effectingchange/ effectingchange1/spotlight/abstractpapers/ColinBarnesWEB.doc/accessed 15 May 2005

Bayard, M. 1999. 'Introduction', In O'Hara (1999, pp. 8-13)

Borsay, A. 2005. Disability and Social Policy in Britain since 1750 (Basingstoke, Palgrave Macmillan)

Church, D. 2006. "“Welcome to the atrocity exhibition": Ian Curtis, rock death, and disability', Disability Studies Quarterly, 26/4 (Fall 2006), http://www.dsq-sds-archives.org/_articles_html/2006/fall/church. asp accessed 30 October 2008

Cooper, M. 2008. 'Against the tide': interview with Neil Young, The Observer Music Monthly, October, pp. 16-22

Cooper, T. 2005. 'The return of the likely lad', The Independent, 8 November, p. 48

Cox, P. 2008. Set into Song: Ewan MacColl, Charles Parker, Peggy Seeger and the Radio Ballads (N.p., Labatie Books)

Crowe, C. 1979. Interview with Joni Mitchell, Rolling Stone, 26 July, http://www.jmdl.com/library/view. cfm?id=300\&ss=polio accessed 14 September 2005

Davis, F. 2000. 'Charlie Haden: bass', The Atlantic Monthly, August, http://www.theatlantic.com/issues/ 2000/08/davis.htm accessed 11 July 2008

Drury, J. 2003. Ian Dury and the Blockheads: Song by Song (London, Sanctuary)

Gleeson, B. 1999. Geographies of Disability (London, Routledge)

Goodman, A. 2006. 'Jazz legend Charlie Haden on his life, his music and his politics', Democracy Now! The War and Peace Report, 1 September, http://www.democracynow.org/2006/9/1/jazz_legend_charlie_ haden_on_his accessed 11 July 2008

Gould, T. 1995. A Summer Plague: Polio and its Survivors (Yale University Press)

Harker, B. 2007. Class Act: The Cultural and Political Life of Ewan MacColl (London, Pluto Press)

Hebdige, D. 1979. Subculture: The Meaning of Style (London, Methuen)

Heslam, D. (ed.) 1992. The NME Rock ' $n$ ' Roll Years (London, BCA)

Houston, F. 2000. 'Brilliant careers: Joni Mitchell', Salon.com 4 April, http://www.jmdl.com/library/view. cfm?id=485\&ss=polio accessed 14 September 2005

Index on Censorship. 1998. Vol. 27/6, November, special edition entitled 'The Book of Banned Music'

Kuppers, P. 2003. Disability and Contemporary Performance: Bodies on Edge (London, Routledge)

Leitch, D. 2005. The Autobiography of Donovan: The Hurdy-Gurdy Man (New York, St Martin's Press), excerpts at http://www.amazon.com/Autobiography-Donovan-Hurdy-Gurdy-Man/dp/product-description/ $0 3 \longdiv { 1 2 3 5 2 5 2 2 }$ accessed 10 October 2008

Lerner, N. 2006. 'The horrors of one-handed pianism: music and disability in The Beast with Five Fingers', in Lerner and Strauss (2006, pp. 75-89)

Lerner, N., and Straus, J.N. (eds.) 2006. Sounding Off: Theorizing Disability in Music (London, Routledge)

Lydon, J. 1994. Rotten: No Irish, No Blacks, No Dogs, with Keith and Kent Zimmerman (London, Hodder and Stoughton)

Mandel,H. 2003. 'Downbeat interview with Dave Liebman', http://www.daveliebman.com/Other_Sites/ downbeat.htm accessed 9 July 2008

Matteo, S. In.d. 'Women of heart and mind: a rare interview with Joni Mitchell', The Inside Connection, http://www.insidecx.com/interviews/i49.asp accessed 9 July 2008

McKay, G. [n.d.] OR Boy: A Norfolk Punk Spills the Beans, unpublished manuscript

McLeod, K. 2001. 'Bohemian Rhapsodies: operatic influences on rock music', Popular Music, 20/2, May, pp.

189-203, http://home.comcast.net/ collaros623/bohemianRhapsodies.pdf accessed 13 October 2008

Muirhead, B. 1983. Stiff: The Story of a Record Label (Poole, Blandford)

O'Hara, C. 1999. The Philosophy of Punk: More than Noise, revised edition (Edinburgh, AK Press)

Palmer, R. 2004. 'CeDell Davis', http://www.fatpossum.com/artists/cedell.html accessed 5 October 2008

Polydor. 1981. Press release for Ian Dury single 'Spasticus Autisticus', POSP/X 285, 21 August 1981

Riverfront Times. 1996. 'Israel Vibration: modern roots with a message', http://www.skankproductions.com /articleiv.htm accessed 1 November 2005

Rutty, C.J. 1988. "Helpless"; the 1951 polio outbreak; the Neil Young case', original essay supplied by the author; also published in A. Jenkins (ed.), Neil Young and Broken Arrow: On a Journey Through the Past (Mid 
Glamorgan, Wales, Neil Young Appreciation Society), 1994, pp. 95-112; see also Rutty's website on polio history, http:// www.healthheritageresearch.com accessed 5 May, 8 June 2005

Sanborn, D. [n.d.] Official website, http://www.davidsanborn.com] accessed 1 November 2005

Savage, J. 1991. England's Dreaming: Sex Pistols and Punk Rock (London, Faber)

Schermer, V.L. 2008. 'Dave Liebman/Jim Ridl: the creative process in jazz', http://www.allaboutjazz.com /php/article.php?id=28416 accessed 9 July 2008

Shell, M. 2005. Polio and its Aftermath: The Paralysis of Culture (Cambridge, Harvard University Press)

Stras, L. 2006. 'The organ of the soul: voice, damage, and affect', in Lerner and Strauss (2006, pp. 173-84)

Thomson, R.G. (ed.) 1996. Freakery: Cultural Spectacles of the Extraordinary Body (New York, New York University Press)

1997. Extraordinary Bodies: Figuring Physical Disability in American Culture and Literature (New York, Columbia University Press)

2000. 'Staring back: self-representations of disabled performance artists', American Quarterly, 52/2, pp. 334-8

Wimmer, B [n.d.] 'Pianist Horace Parlan created his own technique', Berman Music Foundation, http:// www.bermanmusicfoundation.org/hprlnus.htm accessed 26 October 2005

Wise, T. 2007. 'Yodel species: a typology of falsetto effects in popular music vocal styles', Radical Musicology, 2, 57 pars, http://www.radical-musicology.org.uk/2007/Wise.htm accessed 16 October 2008

\section{Discography/filmography}

Cockney Rebel, 'Psychomodo', The Psychomodo. EMI Records, EMC 3033. 1974

'The Last Feast', The Quality of Mercy. GOTT Discs, GOTT CD040. 2005

Ian Dury, 'Sweet Gene Vincent', New Boots and Panties. Stiff Records. 1977

'Dance of the Screamers', Do It Yourself. Stiff Records. 1978

'Hey, Hey, Take Me Away', Laughter. Stiff Records. 1980

'Spasticus Autisticus'. Polydor Records, POSP/X 285. 1981

Israel Vibration, 'Level Every Angle', Fighting Soldiers. Nocturne, NTCD 131. 2002

Stanley Kubrick, dir., Spartacus. 1960

Ewan MacColl, Charles Parker and Peggy Seeger, The Body Blow (first broadcast, BBC Radio, Home Service, 27 March 1962). Topic Records, TSCD 805. 1999

Carl Perkins, Introducing ... Carl Perkins. Dootone Records (reissued by Boplicity Records in 1996), CDBOP 008. 1956

Martin Scorsese, dir. 1978, The Last Waltz. Film re-released, MGM. 2002

Sex Pistols, 'Bodies', Never Mind the Bollocks ... Here's the Sex Pistols. Virgin, V2086. 1977

Neil Young, 'Helpless', On Crosby, Stills, Nash \& Young, Déjà Vu. Atlantic Records. 1970 